\title{
Tax professionals' role and ethics during a period of economic crisis in a small European country
}

\author{
Michail Pazarskis ${ }^{\mathrm{a}, 1}$, Athanasia Karakitsiou ${ }^{\mathrm{a}}$, Andreas Koutoupis ${ }^{\mathrm{b}}$ \\ and Despoina Sidiropoulou ${ }^{\mathrm{a}}$
}

${ }^{a}$ International Hellenic University, Greece

${ }^{\mathrm{b}}$ University of Thessaly, Greece

\begin{abstract}
Research Question: This paper analyses the role and ethics of tax professionals in the collection of public revenue from business activity during a period of economic crisis in Greece.

Motivation: We attempt to analyse the respective influences of a corporate environment and personal beliefs on tax professionals' ethics as well as the consequences of economic crisis. Idea: The paper employs a modified experimental questionnaire from Bobek \& Radtke (2007) for the US. This questionnaire is adapted for Greece during a period of economic crisis.

Data: Addressees of the questionnaire were tax professionals of two categories: certified public accountants and accountant/tax consultants, both of which are responsible for determining the amount of taxes owed to the Greek Independent Public Revenue Authority (IPRA).

Tools: Results were reached by submitting the results of a questionnaire to a multiplecorrespondence analysis based on the Burt matrix. As the size of the sample is rather small, in order to avoid any bias the study employs a resampling procedure based on the $\mathrm{k}$ fold validation method.

Findings: The results of the survey showed that the main causes of ethical dilemmas are problems with clients such as pressure from clients, client-retention concerns and misunderstandings with clients. The major factor contributing to the resolution of an ethical dilemma is the experience of the tax professional. A significant percentage of respondents believed that their level of morality had increased during the period of economic crisis, making them more compliant with relevant tax rules.
\end{abstract}

${ }^{1}$ Corresponding author: Assistant Professor, Department of Economics, International Hellenic University; University Campus of Serres, End of Magnesias Str., GR-62124, Serres, Greece; tel. (+30) 2321049 306; email address: pazarskis@ihu.gr 
Contribution: This study contributes to business ethics and helps reinforce them, thereby contributing to the increase in the public revenues, which can help a economy to emerge faster from an economic crisis. Also, we recommend the targeting on in-house ethics training and explicitly including rewards and sanctions regarding ethical behavior in performance evaluation systems in tax professionals' firms.

Keywords: tax professionals; ethics; public revenues; tax compliance; Greece.

\section{JEL codes: $\mathrm{H} 20 ; \mathrm{M} 40$}

\section{Introduction}

Accounting ethics deal with the auditor's conduct as regards the integrity and objectivity of business transactions. Lack of ethical behaviour results in a limitation on public revenue collection, thus, jeopardising proper execution of a state's budget (Drogalas et al., 2018). The present study explores the relationship between the ethical element of both accounting and tax practice to public revenue collection within the context of an economic crisis which Greece has recently faced (from 2010 to 2017).

The modern tax professional plays a critical role during an economic crisis. His job entails accounting but he also plays the role of a financial analyst or an investment consultant. He may promote tax consciousness so as to facilitate the collection of public revenue for the state (Saad, 2014). A major challenge for the tax professional is dealing with conflict between the financial interests of his clients and the public interest. Thus, ensuring compliance with tax rules is subject to some ambiguity (Bobek et al., 2010).

Tax professionals contribute to enhanced tax compliance when they advocate the correct application of relevant legislation. On the other hand, when their advice is provided for the purpose of committing tax evasion or securing tax exemptions by exploiting the ambiguities or loopholes which exist in every tax system, they are responsible for non-compliance (Backof et al., 2016; Gracia \& Oats, 2012). Particularly in times of economic crisis such as Greece's situation recently, tax professionals must maintain high standards to improve their own position and market share as well as to contribute to the improvement of the country's overall economic climate. However, it is exactly in these times of economic crisis that clients' financial interests seem more critical and ethics may be compromised.

Within this context, tax professionals have had to deal with multiple, often conflicting acts of legislation and have been pressured to satisfy conflicting interests. They must apply relevant legislation while protecting clients from high taxation. Ethics serve as a mediator between the state and the taxpayer as tax professionals 
offer guidance and information about possible exemptions from relevant legislation, all the while keeping within the legal framework (Mulligan \& Oats, 2016). In some cases, the line dividing tax avoidance (which is legal) and tax evasion (which is illegal) is unclear, and it is up to the tax professional to strike the right balance (Shafer \& Simmons, 2008). To reduce falsification of financial statements and tax evasion situations, the tax professional is expected to school clients in tax consciousness and even to inform prosecuting authorities about instances of tax evasion (Drogalas et al., 2017; 2018; Pazarskis et al., 2017). The US tax system, like those of almost all developed states, is based on voluntary compliance, which calls for a professional and personal code of ethics. For this reason, the present study stands to reveal information highly relevant to economic stability.

Every financial scandal entails a severe lack of morality. As US President Roosevelt said, 'To educate a man in mind and not in morals is to educate a menace to society'. Therefore, the study of moral values and the type of dilemmas tax professionals encounter during their work, as well as the mental context of tax consultants and how this affects the prioritization of moral reasoning, which in turn might influence decision making processes, is of particular importance. It is also important to consider the impact that each country's tax framework might have on rational ethics used by each tax professional or accountant, especially when there is a general economic crisis. It is believed that the ambiguity and gaps in tax legislation contribute towards that direction.

The purpose of this study is to examine the role and ethics of certified auditors and accountants in Greece. To the best of our knowledge this is the first study that try investigates tax professionals' role and ethics in the collection of public revenue during the economic crisis in Greece. By using a modified experimental questionnaire from Bobek and Radtke (2007) for the US, the received data is being studied during the period of economic crisis in Greece with a multiple correspondence analysis based on Burt matrix, as a data analysis technique for nominal categorical data. The structure of the paper is as follows: At the next section a brief note for the tax system and economic crisis in Greece is presented, while after that a literature review with relevant earlier studies on the subject is provided. At the next sections the selected research methodology is presented, along with the survey sample and the way of examining the results of the questionnaire. At the next section we provide the results of our study and the last section we discuss results and provide various conclusions.

\section{Tax system and economic crisis in Greece}

Over the past several years (from 2010 to 2017), international rating agencies have continuously downgraded Greece's credit ratings, which have marred its image, leaving Greek banks with few options and the Greek economy on the verge of bankruptcy. Borrowing has led to tough measures. Since 2010, the country's 
economy has suffered a long-term recession despite three support programs (memoranda) with the 'troika': the European Union (EU), the International Monetary Fund (IMF) and the European Central Bank (ECB). As the Greek economic crisis reached its peak in 2013 and 2014, continuing policies of economic austerity, increased corporate tax rates and capital controls further exacerbated the difficulties faced by businesses (as well as households) in their transactions (Pazarskis et al., 2017). This has resulted in severe liquidity problems for banks, and the Greek government has been forced to guarantee loans for the weakened banks, now unable to borrow from the interbank market. Key elements of the Greek recession include increases in unemployment, increases in direct and indirect taxes, a private-sector liquidity crisis, a reduction in investments, a reduction in household disposable income, a reduced number of civil servants and reduced pensions.

This study examines the role and ethics of certified auditors and accountants (more specifically, certified public accountants and accountants - tax consultants) in the collection of public revenues by the Independent Public Revenue Authority (IPRA) in Greece. These two categories of tax professionals were selected as they submit the amount of due taxes at Greek IPRA. They have already faced the ethical dilemmas, as well as the pressures they receive from the corporate environment or external factors regarding tax evasion and compliance. The dramatic impact of an economic crisis on corporate taxation, entrepreneurship and profitability may push tax professionals to find ways to reduce their clients' taxes owed. However, tax professionals must remain ethical in such times, protecting and respecting relevant tax legislation, both for their own sake and for the improvement of the country's financial situation. There is a common belief that the crisis plaguing the economy is characterized by a lack of confidence. Ethics are a crucial concern for the proper conduct of the tax professional and consequently for the proper functioning of the economy (Armstrong et al., 2012).

Last, a special feature of the Greek tax system is its excessive complexity, which is mainly due to the complexity of tax laws and regulations. Although fragmented attempts to simplify the tax system have been made in recent years, these do not seem to have been successful, as complexity has grown over time (Lazos, 2016). In addition, the constant changes in the tax legislation and the increase of the tax burdens have a negative effect on the strengthening of entrepreneurship and on the attraction of new investments (Karagiorgos et al., 2019). The implementation of a new tax law is expected to have an impact on the tax burden on businesses and the decisions they are called upon to make, as well as on public revenue (Pazarskis et $a l ., 2019)$. Moreover the bureaucracy that is inextricably linked to the complexity of the tax system, the economic crisis that affects daily life and trust in the tax authorities is important issues that seem to affect citizen's crisis (Karagiorgos et al., 2020). 


\section{Literature review}

Tax professionals' role and ethics in the collection of public revenue during Greek economic crisis have not been examined, to the best of our knowledge, in recent studies for the Greek market, while the whole research subject for a period of economic crisis, even if it is very interesting, we consider that is not well explored worldwide (Curtis et al., 2017; Espinosa-Pike \& Barrainkua, 2019; Hageman \& Fisher, 2016; McLeod et al., 2016). From this point, of the absence of studies for the Greek market and from a list of limited researches worldwide the present section presents some quite relevant studies (but not exactly on this research subject) for Greece and some of the major studies in this area.

One initial research for tax evasion and ethics in Greece were published by Drogalas et al. (2018), which argued that tax evasion is an economic and social phenomenon. Taxpayers commit tax evasion if they consider that public money is not allocated efficiently from the public sector or if they try to receive more personal gains. Their study explored tax ethics of Greek citizens in the period of Greek economic crisis and compared them with those of other countries, from studies that applied a research model developed by Prof. R.W. McGee. Drogalas et al. (2018) claimed that Greek citizens do not evade taxes due to potential personal gains but rather because they believe that the state is incapable of proper allocation of tax revenues and because current tax system is inefficient or corrupted.

From the other part, accounting professionals face frequent task interruptions that could compromise the quality of their professional judgments. Long and Basoglu (2016) focused on this subject by adopting a Goal-Based Choice Model so as to predict the conditions under which task interruption impair accountants' motivated reasoning (thus, introducing bias into their professional judgments) and reduce performance on the interrupting task. Long and Basoglu (2016) conducted an experiment using experienced tax professionals as participants. Their results showed that when tax professionals are highly committed to a directional goal (minimize the client's tax liability), task interruption impairs their motivated reasoning, increases their perceptions of the level of support for an aggressive tax compliance position, supports their confidence in its defensibility, and compromises their ability to objectively evaluate the risks associated with the situation. As tax ethics attract the interest of researchers worldwide, Darmayasa and Aneswari (2015) in their study explored extensively the ethical practice of tax consultant at the Tax Consulting Firm Nyoman Polos. Their results showed that the professional ethics of tax consultant is emphasizing more at the aspect of formality. This means that an idealist will apply ethics in providing tax consulting services. Darmayasa and Aneswari (2015) concluded that ethical practices of tax consultants based on local culture enable them to increase voluntary tax compliance. 
For the US market, DeZoort et al. (2012) encountered the traditional advocacy role of tax professionals who face growing pressure to help manage the tax fraud problem. DeZoort et al. (2012) proposed as an evaluating method several questions about how the tax professionals perceive fraud detection duties. They analysed 236 tax professionals' opinions on perceived responsibility for tax fraud detection, and the extent that tax engagement type (planning versus compliance) and audit client status (audit client versus not an audit client) affect responsibility. DeZoort et al. (2012) found that reported detection responsibility varies across tax engagement type and audit client status. Also for the US market, Bobek et al. (2010) examined the perceptions of tax partners in comparison to non-partner tax practitioners regarding their Certified Public Accountants (CPA) firms' ethical environment, along with their experiences on ethical dilemmas. Bobek et al. (2010) showed that tax partners rate the ethical environment of their firms as stronger than non-partner tax practitioners. Overall, Bobek et al. (2010) provided evidence that a disconnection between tax partners and non-partner tax practitioners exist, with respect to the notion of organizational ethics.

Another study for tax professionals' ethics were made by Shafer and Simmons (2008), which investigated the effects of attitudes toward the perceived importance of corporate ethics and social responsibility by surveying tax professionals in Hong Kong. Their study incorporated the parameter of Machiavellianism, as a general measure of the propensity for manipulative and deceitful behaviour, on tax professionals' willingness to participate in aggressive tax avoidance schemes of corporate clients. Shafer and Simmons (2008) stated that high Machiavellians are more likely to adopt the traditional 'stockholder view' of corporate responsibility (which states that corporations have little responsibility beyond maximising their profits), and less likely to support the 'stakeholder view' (which recognises corporate responsibilities to a broader range of potential stakeholders). Furthermore, Kadous and Magro (2001) conducted an experiment and found that tax professionals process information differently for clients of different risk levels. Specifically, tax professionals weight negative outcome information more heavily when forming likelihood assessments for a high-risk client, in comparison with a low-risk client. Furthermore, Kadous and Magro (2001) claimed that risk directly affects recommendations in a way that tax professionals more strongly recommend an aggressive position for a low-risk client.

Bobek and Radtke (2007) analysed the ethical environment in which tax professionals operate by eliciting practicing tax professionals' personal experiences with ethical dilemmas arising during tax engagements. They tried to find and reveal tax professionals' self-identified ethical dilemmas which would be related to their assessments of the ethical environment of their firms. Bobek and Radtke (2007) proceeded with an analysis based on 146 responses from practicing tax professionals. Most participants rated their ethical environment as very strong. Additionally, the 84 participants who did not describe a self-identified ethical dilemma rated the ethical 
environment of the firms significantly stronger than the 62 who reported a dilemma. In another study the role of tax professionals in development of recommendations for clients was examined by O'Donnell et al. (2005). They evaluated the practicing tax professionals based on two experiments. Their results suggest that outcome expectations about whether a position can be defended are positively associated with aggressive recommendations. O'Donnell et al. (2005) supported that as complexity increases, professionals with more procedural knowledge propose less aggressive recommendations and rely more heavily on their outcome expectations. These findings illustrate the importance of accounting for knowledge as a two-dimensional construct.

\section{Research design}

\subsection{Questionnaire}

The purpose of this study is to investigate the ethical environment in which tax professionals work and operate, and whether they are ready to implement their company ethical code of conduct in relation to the tax law in force in Greece during the period of the economic crisis. It also explores the role of ethics in the tax and accounting profession and how this affects the revenue collection of the state apparently (Battaglini et al., 2019).

The study follows a modified methodology with an experiential questionnaire of Bobek and Radtke (2007). The survey was conducted to extract the personal views and experiences of: (a) Certified Public Accountants and (b) Accountants - Tax consultants, about the ethical dilemmas they have already faced, as well as the pressures they receive from the corporate environment or external factors regarding tax evasion and compliance. It is also intends to measure general attitudes and perceptions towards the usual situations of moral dissatisfaction. Our questionnaire is experimental, thus it is analytical and contains many detailed questions in order to be able to draw precise conclusions on an ambiguous, complex and subjective issue as ethics is, especially in a period of economic crisis (Bobek \& Radtke, 2007; Bobek et al., 2010). The contribution of the questionnaire to the research and the knowledge it provide us through its thematic units together with the use the answers given to us will lead us to what safe conclusions about the ethics of tax professionals and their role in the Greek economy.

This research will provide to us information on how tax professionals face and react to various ethical problems as well as useful input on how a tax professional faces problems of corruption (Doyle et al., 2014). One additional reason on why we chose to conduct the research using such a comprehensive questionnaire is that in Greece there are different attitudes towards tax evasion in conjunction with the high rates of tax evasion (Drogalas et al., 2018). Moral dilemmas faced by tax professionals are diverse and complex (Cohen et al., 2017; 2018; Ishaque, 2019). However, tax 
professionals can play an important role in reducing corruption of taxpayers and by providing expertise to companies through ethical acting (DeZoort \& Harrison, 2018).

Combination of respondents' answers to the variety of questions can contribute to gain a better understanding of the average way of thinking of tax practitioners. This combination can lead us to useful and clear conclusions. Thus, our survey is quantitative and is using a questionnaire (Bobek et al., 2012; 2015b). The questionnaire contains 22 questions in four sections. The first one refers to the required demographic information of the study (Bobek et al., 2015a; 2017; 2018). In the second set of questions, we investigate whether the corporate environment is ethical and whether the organizational culture reflects the common perceptions of employees (Baker et al., 2014; Baird \& Harrison, 2017; Dalton et al., 2019). The third set of questions investigates ethical dilemmas and aims to measure the severity and frequency of most common cases, as well as who is involved and in what way. It also aims to investigate what are the possible causes of the identified moral dilemmas and how to solve them. Finally, we also investigate how all of the above are affected by the fact that our survey is taking place in Greece, which is affected from 2010 to 2017 by a severe economic crisis.

\subsection{Sample}

The sample consists of 53 people, who come from two main categories: (a) certified public accountants and (b) accountants - tax consultants. The tax professionals of these two categories were selected as they submit the amount of due taxes at Greek IPRA. The selection of experienced professionals with years of experience in the field and with good knowledge among others is the most important element for the succession of our research. Our questionnaire was asking for anonymity. We contacted respondents either via e-mail or via the dissemination of the questionnaire (Google forms application) electronically during the last four months of the year 2018. General demographic information of the sample is shown at the following table.

Table 1. Demographic information

\begin{tabular}{lccc}
\hline & $\begin{array}{c}\text { Accountants and } \\
\text { Tax consultants }\end{array}$ & $\begin{array}{c}\text { Certified Public } \\
\text { Accountants }\end{array}$ & $\begin{array}{c}\text { Total } \\
\text { Sample }\end{array}$ \\
\hline Number Distributed & 123 & 48 & 171 \\
Number Responding & 33 & 20 & 53 \\
(Response Rate) $^{\text {Years of Experience }}{ }^{1}$ & $26.82 \%$ & $41.66 \%$ & $30.99 \%$ \\
$\quad$ Mean & 3.50 & 3.47 & \\
$\quad$ (S.D.) & 1.499 & 1.405 & 3.50 \\
Firm Type & & & 1.499 \\
$\quad$ Big 4 & $3 \%$ & $20 \%$ & $9.4 \%$ \\
$\quad$ S.O.E.L. & $3 \%$ & $30 \%$ & $11.3 \%$ \\
& & &
\end{tabular}

Vol. 19, No. 4 


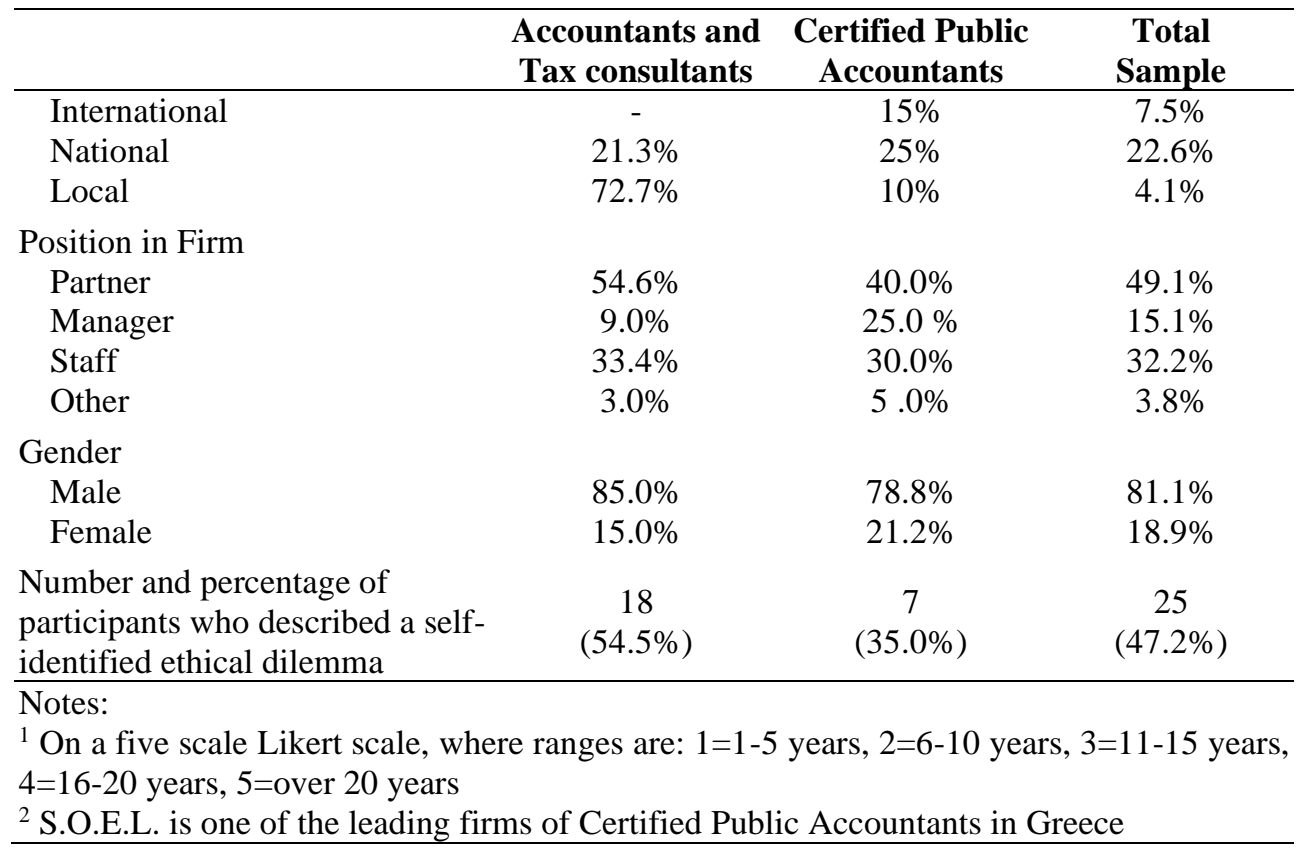

Based on results from Table 1 the participants are quite experienced as 52.8\% have experience over 16 years. Most were from local businesses $49.1 \%$ and were $81.1 \%$ men. Finally, $47.2 \%$ of the participants experienced an ethical dilemma that would lead to a reduced collection of public revenues.

\subsection{Methodology}

The aim of this work is to access the role of tax professionals' role and ethics in the collection of public revenue during the period of economic crisis in Greece (from 2010 to 2017). Toward this direction a research was conducted using a modified version of the experiential questionnaire proposed by Bobek and Radtke (2007). In order to find out the underling patterns of association of the variables obtained from the questionnaire (apart from the descriptive statistics' results evaluation, as mean, standard deviation, percentages etc.) the Multiple Correspondence Analysis (MCA) was employed.

Correspondence analysis (CA) is a descriptive, exploratory technique of multivariate statistical analysis, allowing defining the nature and structure of the relationship between qualitative variables. It identifies patterns of association and disassociation in those data. The technique presents its results in the form of a two-dimensional plot, which visualises these relationships in an intuitive manner. In correspondence analysis it is claimed that no underlying distribution has to be assumed and no model has to be hypothesized, but a decomposition of the data is obtained in order to study their "structure" (Greenacre, 2007). 
The Multiple Correspondence Analysis is an extension of CP which allows the summarization of information in a data set containing individuals/observation described by multiple intercorrelated qualitative variables. It is most commonly used to analyse data obtained through surveys: in such a context, each question corresponds to a categorical variable and each possible answer to the question corresponds to a category of that variable. MCA is performed by applying the Correspondence Analysis (CA) algorithm to either an indicator matrix (also called complete disjunctive table - CDT) or a Burt table formed from these variables (Greenacre, 2007).

Burt table is a square table of $K \times K$ dimensions, where each row and each column correspond to one of the categories $K$ of the set of variables. In the cell $\left(k_{n}, k_{n+1}\right)$ we observe the number of individuals who carry both categories $k_{n}$ and $k_{n+1}$. This table is an extension of the contingency table where there are more than two categorical variables: it juxtaposes all of the information from the contingency table of variables taken as pairs (in rows and columns).

B

$=\left[\begin{array}{ccccccc}\mathrm{k}\left(\mathrm{x}_{1}, \mathrm{x}_{1}\right) & \mathrm{k}\left(\mathrm{x}_{1}, \mathrm{x}_{2}\right) & \cdots & \mathrm{k}\left(\mathrm{x}_{1}, \mathrm{x}_{\mathrm{n}}\right) & \mathrm{k}\left(\mathrm{x}_{1}, \mathrm{x}_{\mathrm{n}+1}\right) & \cdots & \mathrm{k}\left(\mathrm{x}_{1}, \mathrm{x}_{\mathrm{m}}\right) \\ \mathrm{k}\left(\mathrm{x}_{2}, \mathrm{x}_{1}\right) & \mathrm{k}\left(\mathrm{x}_{2}, \mathrm{x}_{2}\right) & \cdots & \mathrm{k}\left(\mathrm{x}_{2}, \mathrm{x}_{\mathrm{n}}\right) & \mathrm{k}\left(\mathrm{x}_{2}, \mathrm{k}_{\mathrm{n}+1}\right) & \cdots & \mathrm{k}\left(\mathrm{x}_{2}, \mathrm{x}_{\mathrm{m}}\right) \\ \vdots & \vdots & \vdots & \vdots & \vdots & \vdots & \vdots \\ \mathrm{k}\left(\mathrm{x}_{\mathrm{n}}, \mathrm{x}_{1}\right) & \mathrm{k}\left(\mathrm{x}_{\mathrm{n}}, \mathrm{x}_{2}\right) & \cdots & \mathrm{k}\left(\mathrm{x}_{\mathrm{n}}, \mathrm{x}_{\mathrm{n}}\right) & \mathrm{k}\left(\mathrm{x}_{\mathrm{n}}, \mathrm{x}_{\mathrm{n}+1}\right) & \cdots & \mathrm{k}\left(\mathrm{x}_{\mathrm{n}}, \mathrm{x}_{\mathrm{m}}\right) \\ \mathrm{k}\left(\mathrm{x}_{\mathrm{n}+1}, \mathrm{x}_{1}\right) & \mathrm{k}\left(\mathrm{x}_{\mathrm{n}+1}, \mathrm{x}_{2}\right) & \cdots & \mathrm{k}\left(\mathrm{x}_{\mathrm{n}+1}, \mathrm{x}_{\mathrm{n}}\right) & \mathrm{k}\left(\mathrm{x}_{\mathrm{n}+1}, \mathrm{x}_{\mathrm{n}+1}\right) & \cdots & \mathrm{k}\left(\mathrm{x}_{\mathrm{n}+1}, \mathrm{x}_{\mathrm{m}}\right) \\ \vdots & \vdots & \vdots & \vdots & \vdots & \cdots & \cdots \\ \mathrm{k}\left(\mathrm{x}_{\mathrm{m}}, \mathrm{x}_{1}\right) & \mathrm{k}\left(\mathrm{x}_{\mathrm{m}}, \mathrm{x}_{2}\right) & \cdots & \mathrm{k}\left(\mathrm{x}_{\mathrm{m}}, \mathrm{x}_{\mathrm{n}}\right) & \mathrm{k}\left(\mathrm{x}_{\mathrm{m}}, \mathrm{x}_{\mathrm{n}+1}\right) & \cdots & \mathrm{k}\left(\mathrm{x}_{\mathrm{m}}, \mathrm{x}_{\mathrm{m}}\right)\end{array}\right]$

As the size of the sample is rather small, in order to avoid any bias the study employs a resampling procedure based on the $\mathrm{k}$ fold validation method. Indeed, resampling methods are broadly accepted for small samples from small countries as Greece.

\section{Results}

\subsection{Questionnaire analysis}

Based on Table 2, we analyze below the participant's answers on how they assess the ethical scale in their work environment. We are trying to investigate the scale of ethics in the working environment through three sub-types of questions. The first explores the perceptions of tax professionals on ethics in their work environment, as well as the influence of leadership on maintaining or encouraging ethical behavior. Participants' responses are analyzed on whether they believe or believe that their company has strong values and cares about their moral behavior (mean 4.47 and standard deviation 0.558). The majority of them have rated their work environment 
as very ethical. Also, whether their managers and colleagues act ethically and encourage ethical behavior (mean 4.36 and standard deviation 0.575). Regarding the question whether they and their colleagues identify themselves with the company's position and comply with the existing legislation and the code of professional ethics and ethics of their company, they consider that they act morally above normal (mean 4.36 and standard deviation of 0.575). Furthermore, they agree that their businesses have strong ethical values and generally have a positive view of organizational ethics (except for 3.8\% who think the working environment is not so ethical).

In the second group, the majority of them believe that their company code of ethics is aligned with existing mandatory legislation (mean 4.46 and standard deviation 0.638 ) and they argue that their companies in Greece have training programs that encourage ethical decision-making (mean 4.28 and standard deviation 0.655).

The final part of Table 2 investigates whether unethical behavior is punishable and whether special recognition is given to ethically active individuals (mean 3.94 and standard deviation 1.088). In this question, we observe that there is a relatively large dispersion in addressing ethical or unethical behavior in the work environment and that rates are lower than other factors, which suggests that improvements should be made in this area (Bobek \& Radtke, 2007).

Table 2. Ethical environment scale

\begin{tabular}{|c|c|c|}
\hline Category & Questions & $\begin{array}{l}\text { Mean } \\
\text { (S.D.) }\end{array}$ \\
\hline \multicolumn{3}{|l|}{ Social Norms } \\
\hline Mission and Values & $\begin{array}{l}\text { (1) As a whole, my firm has strong ethical } \\
\text { values that reinforce ethical decision-making. } \\
\text { (2) My firm is greatly concerned with ethical } \\
\text { behavior. }\end{array}$ & $\begin{array}{c}4.47 \\
(0.558)\end{array}$ \\
\hline $\begin{array}{l}\text { Leadership and } \\
\text { Management Influence }\end{array}$ & $\begin{array}{l}\text { (1) Managers and partners within my firm act } \\
\text { ethically. } \\
\text { (2) Managers and partners within my firm } \\
\text { clearly support all firm efforts to encourage } \\
\text { ethical behavior. }\end{array}$ & $\begin{array}{c}4.36 \\
(0.575)\end{array}$ \\
\hline Peer Group Influence & $\begin{array}{l}\text { (1) Individuals within my firm strongly identify } \\
\text { with the firm. } \\
\text { (2) Colleagues within my firm act ethically. }\end{array}$ & $\begin{array}{c}4.36 \\
(0.633)\end{array}$ \\
\hline Social Practices & $\begin{array}{l}\text { (1) My firm has a code of ethics that is } \\
\text { consistent with the Greek Code of Professional }\end{array}$ & \\
\hline $\begin{array}{l}\text { Procedures, rules, and } \\
\text { Codes of Ethics }\end{array}$ & $\begin{array}{l}\text { Conduct. } \\
\text { (2) Other individuals within my firm adhere to } \\
\text { both the firm's code of ethics and the Greek } \\
\text { Code of Professional Conduct. }\end{array}$ & $\begin{array}{c}4.46 \\
(0.638)\end{array}$ \\
\hline
\end{tabular}


Tax professionals' role and ethics during

a period of economic crisis in a small European country

\begin{tabular}{llc}
\hline Category & \multicolumn{1}{c}{ Questions } & \multicolumn{1}{c}{$\begin{array}{c}\text { Mean } \\
\text { (S.D.) }\end{array}$} \\
\hline \multirow{2}{*}{ Ethics Training } & $\begin{array}{l}\text { (1) My firm has an effective ethics training } \\
\text { program. } \\
\text { (2) My firm's ethics training program focuses } \\
\text { on practical issues and encourages ethical } \\
\text { decision making. }\end{array}$ & $\begin{array}{c}\text { (0.655) } \\
\text { Outcomes }\end{array}$ \\
& $\begin{array}{l}\text { (1) Unethical behavior is severely punished } \\
\text { within my firm. } \\
\text { (2) Special recognition is given to individuals } \\
\text { Rewards and Sanctions }\end{array}$ & $\begin{array}{c}\text { (1.9.084) } \\
\text { firm. }\end{array}$ \\
\hline
\end{tabular}

Table 3 examines how tax professionals evaluated the seriousness and frequency of ten common examples of ethical dilemmas, which are described in detail (Bobek \& Radtke, 2007). With regard to the incidence measured on a five-point scale (with $1=$ very little to $5=$ very much) two ethical dilemmas appeared with the highest frequency which, according to the tax professional's experience, is dependence on the client due to profits (mean 2.51) and the involvement (for the benefit of the client) of control procedures of the Independent Public Revenue Authority (mean 2.24).

Also, Table 3 focuses on whether any of the queries were reported or discussed, whether it was from a non-moral client's proposal and eventually was not solved. We find that the most discussed ethical dilemma was inadequate staff control for a specific activity of $85.7 \%$, followed by the fact that $84.2 \%$ did not report an error in return to client. The ethical dilemma that respondents ranked as the least mentioned was the failure to complete all the work required to pay taxes by $69.2 \%$. With regard to the second factor we are investigating participants, on average $14.17 \%$ faced one of the ten dilemmas, due to a non-ethical client, most notably the failure to perform all the work required to pay taxes at $23.1 \%$.

Table 3. Seriousness and frequency of common examples of ethical dilemmas

\begin{tabular}{lccccc}
\hline \multirow{2}{*}{$\begin{array}{c}\text { Dilemma } \\
\text { Description }\end{array}$} & $\begin{array}{c}\text { Ever } \\
\text { Encountered }\end{array}$ & $\begin{array}{c}\text { Frequency of } \\
\text { Occurrence }\end{array}$ & Reported & $\begin{array}{c}\text { Unethical } \\
\text { client }\end{array}$ & Unresolved \\
\hline & Yes/No & $\begin{array}{c}\text { Possible answers: } \\
\text { 1(very little)- } \\
\text { 5(very much) }\end{array}$ & Yes/No & Yes/No & Yes/No \\
\hline $\begin{array}{l}\text { Undue reliance on } \\
\text { the prior year return }\end{array}$ & $96.22 \%$ & 2.51 & $81.8 \%$ & $13.6 \%$ & $4.5 \%$ \\
$\begin{array}{l}\text { Exploitation of } \\
\text { Greek IPRA audit } \\
\text { process }\end{array}$ & $96.22 \%$ & 2.24 & $82.5 \%$ & $12.5 \%$ & $5.0 \%$ \\
& & & & & \\
& & & & &
\end{tabular}

Vol. 19, No. 4 


\begin{tabular}{|c|c|c|c|c|c|}
\hline \multirow[b]{2}{*}{$\begin{array}{c}\text { Dilemma } \\
\text { Description }\end{array}$} & \multirow[b]{2}{*}{$\begin{array}{c}\text { Ever } \\
\text { Encountered }\end{array}$} & \multicolumn{4}{|c|}{ When an ethical dilemma took place: } \\
\hline & & $\begin{array}{c}\text { Frequency of } \\
\text { Occurrence }\end{array}$ & Reported & $\begin{array}{l}\text { Unethical } \\
\text { client }\end{array}$ & Unresolved \\
\hline $\begin{array}{l}\text { Not determining the } \\
\text { accuracy of client } \\
\text { representations }\end{array}$ & $96.22 \%$ & 1.90 & $74.4 \%$ & $14.0 \%$ & $11.6 \%$ \\
\hline $\begin{array}{l}\text { Failing to obtain } \\
\text { sufficient relevant } \\
\text { data to determine if } \\
\text { conclusions have a } \\
\text { realistic probability } \\
\text { of being sustained }\end{array}$ & $94.33 \%$ & 2.04 & $80.0 \%$ & $12.5 \%$ & $7.5 \%$ \\
\hline $\begin{array}{l}\text { Failing to carefully } \\
\text { plan, staff, or } \\
\text { supervise } \\
\text { engagement }\end{array}$ & $92.45 \%$ & 2.12 & $85.7 \%$ & $9.5 \%$ & $4.8 \%$ \\
\hline $\begin{array}{l}\text { Not reporting an } \\
\text { error in return to } \\
\text { client }\end{array}$ & $94.33 \%$ & 1.56 & $84.2 \%$ & $13.2 \%$ & $2.6 \%$ \\
\hline $\begin{array}{l}\text { Lacking the } \\
\text { appropriate level of } \\
\text { knowledge to } \\
\text { adequately perform } \\
\text { duties required }\end{array}$ & $94.33 \%$ & 1.90 & $82.5 \%$ & $12.5 \%$ & $5.0 \%$ \\
\hline $\begin{array}{l}\text { Misrepresenting or } \\
\text { concealing } \\
\text { limitations in one's } \\
\text { ability to provide tax } \\
\text { services }\end{array}$ & $94.33 \%$ & 1.36 & $79.5 \%$ & $15.4 \%$ & $5.1 \%$ \\
\hline $\begin{array}{l}\text { Not completing all } \\
\text { of the work required } \\
\text { by the terms of the } \\
\text { tax engagement }\end{array}$ & $96.22 \%$ & 1.65 & $69.2 \%$ & $23.1 \%$ & $7.7 \%$ \\
\hline $\begin{array}{l}\text { Recommending a } \\
\text { position that does } \\
\text { not meet the realistic } \\
\text { possibility standard }\end{array}$ & $96.22 \%$ & 1.65 & $74.4 \%$ & $15.40 \%$ & $10.3 \%$ \\
\hline
\end{tabular}

Table 4 lists some of the features of identified ethical dilemmas. Specifically, the type of client is examined, from which $69.8 \%$ is a company, and there may be either co-operation (47.2\%) or not $(52.8 \%)$. It also emerged that it is not happening recently and at high rates, and the owner / main shareholder of the business is usually the one involved in this process. 
Tax professionals' role and ethics during

a period of economic crisis in a small European country

Table 4. Characteristics of identified ethical dilemmas

\begin{tabular}{|c|c|}
\hline Characteristics & $\begin{array}{l}\% \text { ethical } \\
\text { dilemmas }\end{array}$ \\
\hline $\begin{array}{l}\text { Client Type: } \\
\text { Corporate } \\
\text { Individual } \\
\text { Other }\end{array}$ & $\begin{array}{l}69.8 \% \\
30.2 \% \\
-\end{array}$ \\
\hline $\begin{array}{l}\text { Engagement Type: } \\
\text { Tax Only } \\
\text { Tax and other }\end{array}$ & $\begin{array}{l}47.2 \% \\
52.8 \%\end{array}$ \\
\hline $\begin{array}{l}\text { When Occurred: } \\
\text { Within last } 6 \text { months } \\
6 \text { months-1 year ago } \\
1-2 \text { years ago } \\
\text { More than } 2 \text { years ago }\end{array}$ & $\begin{array}{l}9.4 \% \\
5.7 \% \\
28.3 \% \\
56.6 \%\end{array}$ \\
\hline $\begin{array}{l}\text { Client Tenure: } \\
\text { 1st year } \\
\text { 2nd year } \\
\text { 3rd year or more }\end{array}$ & $\begin{array}{l}17.0 \% \\
7.5 \% \\
75.5 \%\end{array}$ \\
\hline $\begin{array}{l}\text { Subject's role in engagement: } \\
\text { Partner } \\
\text { Senior Manager } \\
\text { Manager } \\
\text { Staff } \\
\text { Other }\end{array}$ & $\begin{array}{l}50.9 \% \\
11.3 \% \\
17.0 \% \\
20.8 \% \\
-\end{array}$ \\
\hline $\begin{array}{l}\% \text { of dilemmas with the following other engagement team } \\
\text { members involved: } \\
\text { Partner } \\
\text { Senior Manager } \\
\text { Manager } \\
\text { Staff } \\
\text { Other }\end{array}$ & $\begin{array}{l}35.8 \% \\
17.0 \% \\
22.6 \% \\
3.8 \% \\
-\end{array}$ \\
\hline $\begin{array}{l}\text { Who Initially Encountered Dilemma? } \\
\text { Subject } \\
\text { Other Member of Engagement Team }\end{array}$ & $\begin{array}{l}67.9 \% \\
32.1 \%\end{array}$ \\
\hline $\begin{array}{l}\text { For Business Clients: } \% \text { of dilemmas with the following client } \\
\text { personnel involved: } \\
\text { Owner } \\
\text { CEO } \\
\text { CFO } \\
\text { Accounting Staff }\end{array}$ & $\begin{array}{l}50.9 \% \\
17.1 \% \\
22.6 \% \\
9.4 \%\end{array}$ \\
\hline
\end{tabular}

In Table 5 we provide the possibility of multiple choices for respondents. Regarding the received answers the four main causes of the identified ethical dilemmas were the problems mainly with clients. Thus, with $50.9 \%$, the pressure from the client comes as the first major factor in creating a ethical dilemma, followed by customer 
retention problems $37.7 \%$ and the same number of issues that are created due to misunderstanding by the client $37 \%$. Also, fourth in a selection is the delayed provision of information by the client (32.1\%) as well as unintentional carelessness with $32.1 \%$.

Table 5. Causes of self-identified ethical dilemmas

\begin{tabular}{lc}
\hline Causes & $\begin{array}{c}\% \text { indicating } \\
\text { issue was a factor }\end{array}$ \\
\hline Pressure from client & $50.9 \%$ \\
Client retention concerns & $37.7 \%$ \\
Time constraints: late delivery of information from client & $32.1 \%$ \\
Misunderstanding with client & $37.7 \%$ \\
Limited staffing or firm resources & $7.5 \%$ \\
Competitive external environment & $13.2 \%$ \\
Inadequate review process & $7.5 \%$ \\
Time constraints: poor firm planning & $5.7 \%$ \\
Pressure to complete project under budget & $20.8 \%$ \\
Inadequate training & $7.5 \%$ \\
Internal firm pressure to maximize engagement fees & $11.3 \%$ \\
Internal firm pressure to maximize realization rates & $5.7 \%$ \\
Unintended carelessness & $32.1 \%$ \\
Internal firm pressure to deliver aggressive tax advice & $22.6 \%$ \\
Other & - \\
\hline
\end{tabular}

Table 6-A investigates the final result after identifying ethical dilemmas and how ethical is this for the participants. One of the results was that the ethical dilemma was discussed with the client and the client was satisfied with the result. The tax professionals considered the result quite ethical (mean 3.42). The fact that an ethical dilemma is not solved or overlooked is considered to be unethical, as it also considers it unethical for the client to withdraw from an ethical dilemma that was presented. When the final result after the presentation of an ethical dilemma is to leave the client out of the partnership, the tax professionals do not consider it moral (mean 2.13).

The received answers regarding the results after the recognition of ethical dilemmas have a large standard deviation, which means that there is a great dispersion of how ethical they consider each result. This is because ethics is a difficult part of the tax profession. Moral dilemmas faced by tax professionals are diverse and complex (Cohen et al., 2017; 2018; Ishaque, 2019) and tax professionals can play an important role in reducing corruption of taxpayers and by providing expertise to companies through ethical acting (DeZoort \& Harrison, 2018)

Table $6 \mathrm{~B}$ discusses the extent to which some factors contribute to the solution of ethical dilemma, mainly through the communication of senior executives, colleagues, existing in relation to tax professionals. Finally, the factors that contributed to the solution of ethical dilemmas consider that both the internal (mean 3.55) and external education (mean 3.38) contributed about the same in solving ethical problems. 
Tax professionals' role and ethics during

a period of economic crisis in a small European country

\begin{tabular}{|c|c|c|}
\hline \multicolumn{3}{|c|}{ Panel 6-A: Outcomes of Self-Identified Ethical Dilemmas } \\
\hline \multirow[t]{3}{*}{ Outcomes of self-identified ethical dilemmas } & $\begin{array}{c}\% \\
\text { Responding }\end{array}$ & $\begin{array}{c}\text { Ethical } \\
\text { Environment } \\
\text { Scale Mean }\end{array}$ \\
\hline & \multicolumn{2}{|c|}{ Possible answers: } \\
\hline & Yes/No & $\begin{array}{l}1 \text { (very little) } \\
5 \text { (very much) }\end{array}$ \\
\hline Discussed with client: client satisfied with result & $98.11 \%$ & 3.42 \\
\hline Discussed with client: client not satisfied with result & $88.67 \%$ & 2.30 \\
\hline It was not resolved & $83.01 \%$ & 1.98 \\
\hline It was ignored & $83.01 \%$ & 2.30 \\
\hline Withdrew from engagement & $84.90 \%$ & 2.30 \\
\hline Other & - & - \\
\hline
\end{tabular}

Panel 6-B: Factors Contributing to Dilemma Resolution

\begin{tabular}{lcc}
\hline Factors contributing to dilemma resolution & $\begin{array}{c}\text { \% Indicating } \\
\text { Item Was a } \\
\text { Factor }\end{array}$ & $\begin{array}{c}\text { Ethical } \\
\text { Environment } \\
\text { Scale Mean }\end{array}$ \\
\cline { 2 - 3 } & Possible answers: \\
\hline Yes/No & $\begin{array}{r}\text { 1(very little)- } \\
\text { 5(very much) }\end{array}$ \\
\hline Experience & $96.22 \%$ & 4.20 \\
Personal ethical values or moral beliefs & $94.33 \%$ & 4.26 \\
Communication with client & $98.11 \%$ & 4.04 \\
Communication with superior: on the engagement & $88.67 \%$ & 3.66 \\
Communication with superior: not on the engagement & $86.79 \%$ & 3.20 \\
Communication with peers: on the engagement & $86.79 \%$ & 3.40 \\
Communication with peers: not on the engagement & $86.79 \%$ & 3.11 \\
Communication with subordinates: on the engagement & $84.90 \%$ & 3.11 \\
Communication with subordinates: not on the engagement & $84.90 \%$ & 2.84 \\
Consultation with firm quality control group & $88.67 \%$ & 3.19 \\
Issue was resolved by another person on the engagement & $79.24 \%$ & 2.07 \\
Internal firm training & $88.67 \%$ & 3.55 \\
External firm training & $84.90 \%$ & 3.38 \\
Other & - & - \\
\hline
\end{tabular}

Table 7 investigates how the ethical level changed during the period of the economic crisis in Greece and whether the respondents were involved in unlawful actions to avoid losing a client or in a bribe action for tax evasion or tax evasion. 64.15\% of respondents believe that the level of ethics has changed due to the economic crisis in Greece. Nevertheless, they themselves were not involved in unlawful actions or in tax avoidance actions in order not to lose a client. 
Table 7. Existence and aspects of ethical dilemmas during the economic crisis in Greece

\begin{tabular}{lcc}
\hline Existence and aspects of ethical dilemmas & $\begin{array}{c}\text { \% Indicating } \\
\text { Item Was a } \\
\text { Factor } \\
\text { Possible } \\
\text { answers: }\end{array}$ & $\begin{array}{c}\text { \% Indicating } \\
\text { Item Was a } \\
\text { Factor } \\
\text { Possible } \\
\text { answers: }\end{array}$ \\
\hline During the period of economic crisis in Greece ... & $64.10 \%$ & No \\
\hline $\begin{array}{l}\text { Your level of morality has changed } \\
\text { You have falsified financial statements and data to } \\
\text { avoid losing a customer }\end{array}$ & $5.66 \%$ & $94.34 \%$ \\
$\begin{array}{l}\text { You have ever been involved in a bribe action for tax } \\
\text { evasion }\end{array}$ & $1.90 \%$ & $98.10 \%$ \\
$\begin{array}{l}\text { You have ever been involved in avoiding tax evasion } \\
\text { (eg transferring of tax domicile to another state) in a }\end{array}$ & $9.44 \%$ & $90.56 \%$ \\
$\begin{array}{l}\text { lawful process } \\
\text { You have ever been involved in an act of non-issuance } \\
\text { of invoices for tax evasion, i.e. in the context of an } \\
\text { irregular procedure }\end{array}$ & $1.90 \%$ & $98.10 \%$ \\
\hline
\end{tabular}

\subsection{Data analysis with Burt matrix}

In order to find out the underling patterns of association of the variables obtained from the questionnaire the Multiple Correspondence Analysis (MCA) based on Burt Matrix was employed. The analysis was performed using the factoMineR (Le et al, 2008) and Factoextra (Kassambara \& Mundt, 2017) packages in R.

The first step is to determine the number of dimensions to retain after MCA. A method to determine the number of factors is to look at a Scree Plot, which is the plot of eigenvalues ordered from largest to the smallest. Scree plots are used to help decide how many dimensions are needed to explain the variation in the data. The number of dimensions is determined at the point, beyond which the remaining eigenvalues are all relatively small and of comparable size (Peres-Neto et al., 2005). Figure 1 indicates that the first five dimensions explain about the $81 \%$ of the variation included into the data, which is an acceptable percentage. 


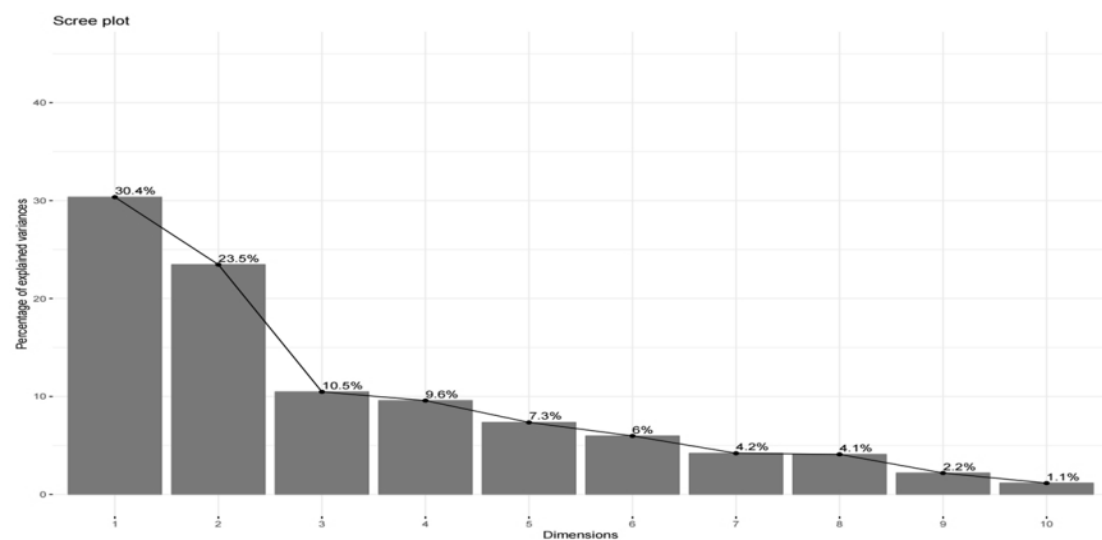

Figure 1. Scree plot of the data

The research was completed by clustering the data in five discrete groups. The following categorization becomes apparent using clustering in an ascendant hierarchy. The latter provides the possibility of grouping a total of 69 variables into 5 groups which is the most satisfactory option, because both the cohesion of the variables in each group and the discernibility among the five groups has been accomplished.

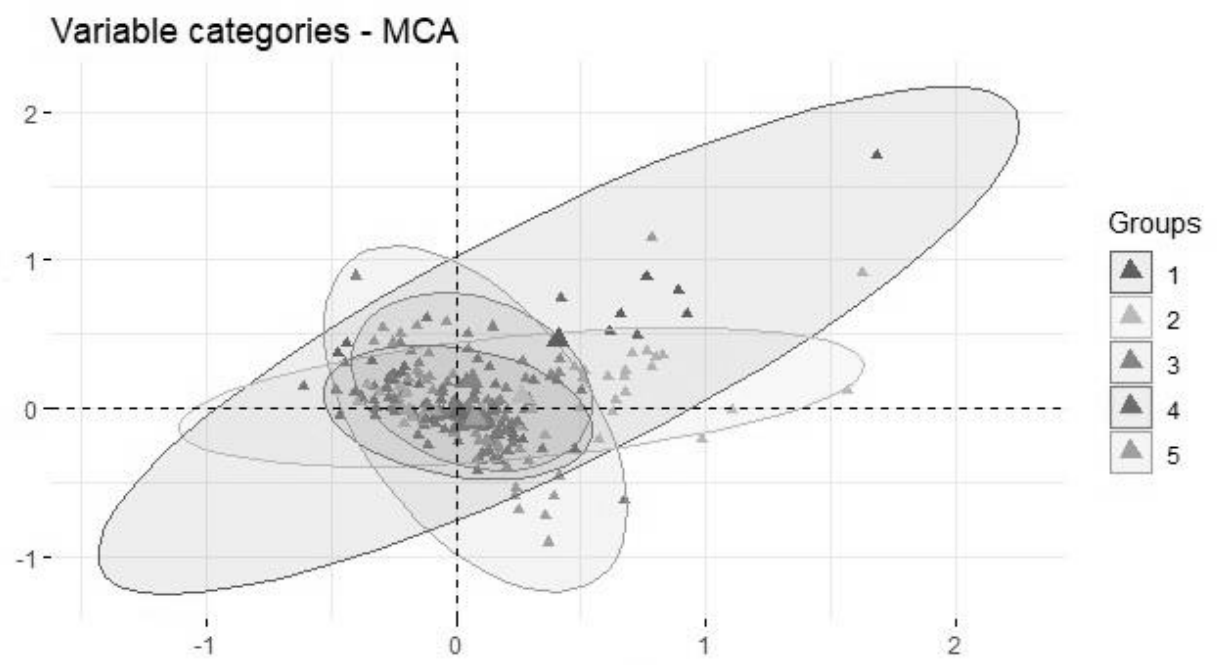

Figure 2. Cluster of variables

For reasons of space economy, we limit our analysis to the most 15 important variables within each group. 
Group 1 consists of Certified Public Accountants (OC_0) who (i) work in the big 4 Certified Public Accountants Offices (TB_0) as managers (PB_1), (ii) the ethical environment in their working places reinforce ethical decision-making a lot (EWP1_3 \& EWP1_4) and their firm is greatly concerned with ethical behaviour (EWP2_3) and the managers act ethically (EWP13_4), (iii) the ethical dilemma they encountered are mainly concerned with: (a) the undue reliance on the prior year return (EXED1_0), (b) the exploitation of IPRA audit process (EXED2_0) (c) not determining the accuracy of client representations (EXED3_1) (iii) they were engaged to these problems as managers (RINTER_3), (iv) the major factor contributing to the resolution of the ethical dilemma were: (a) their experience (FCR1_0), (b) their personal ethical values or moral beliefs(FCR2_0), (v) the ethical dilemmas handled within firm and client not involved (RAR2_3).

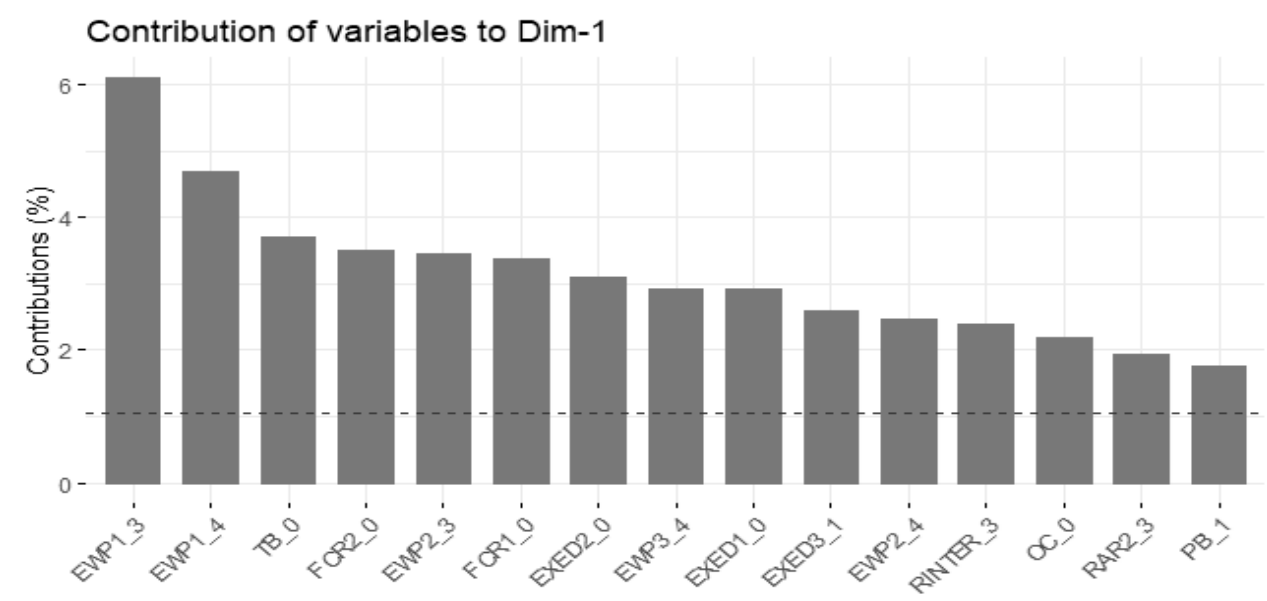

Figure 3. Contribution of variables to Cluster 1

Group 2 consists of Certified Public Accountants (OC_0) who (i) work in SOEL (TB_2) and in national Certified Public Accountants Offices (TB_4) as managers (PB_1) with working experience 1-5 years (WE_0) and 15-20 years (WE_2), (ii) the ethical environment in their working places is greatly concerned with ethical behaviour (EWP2_2), (iii) the ethical dilemma they encountered are mainly concerned the exploitation of IPRA audit process (EXED2_2), (iii) they were engaged to these problems as Senior Manager (RINTER_2) or managers (RINTER_3), (iv) the major factor contributing to the resolution of the ethical dilemma was the communication with a superior (FCR5_3), (v) the ethical dilemmas handled within firm and the client was not involved (RAR2_2). 
Contribution of variables to Dim-2

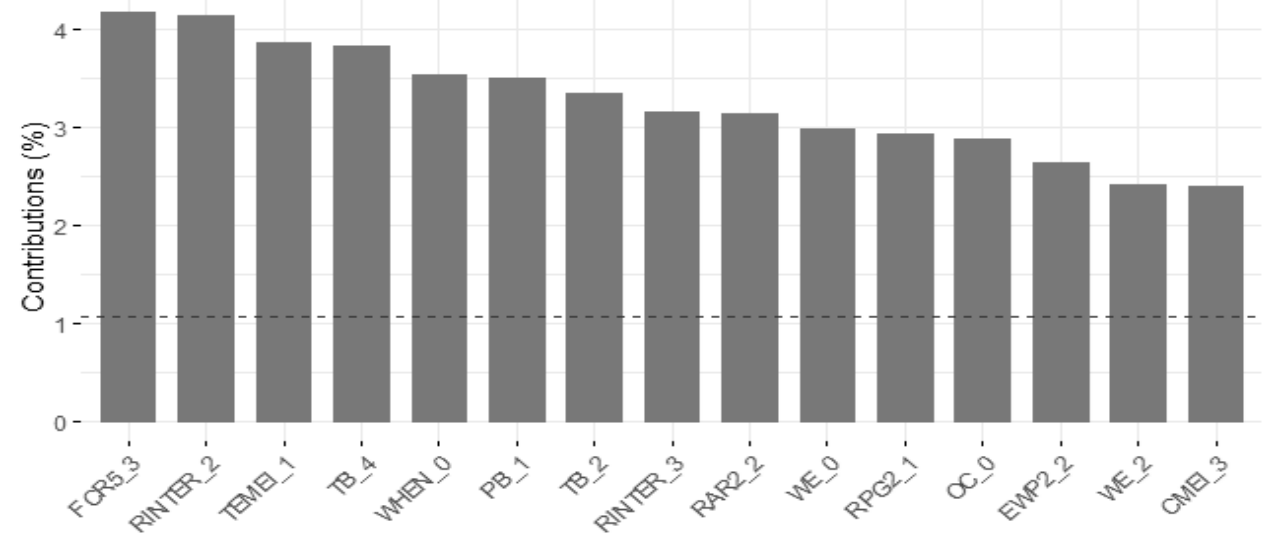

Figure 4. Contribution of variables to Cluster 2

Group 3 consists of professionals who (i) work in SOEL (TP_2) and in national Certified Public Accountants Offices (TB_4), (ii) the ethical dilemma they encountered are mainly concerned the exploitation of IPRA audit process (EXED2_3), (iii) they were engaged to these problems as Partner (RINTER_0) or managers (RINTER_3) together with other partner of the company (TEMEI_2) and the owner of the customer (CMEI_1), (iv) the major factor contributing to the resolution of the ethical dilemma was: (a) their experience (FCR1_4) and their personal ethical values or moral beliefs (FCR2_3), (v) the ethical dilemmas handled within firm and client not involved (RAR2_1).

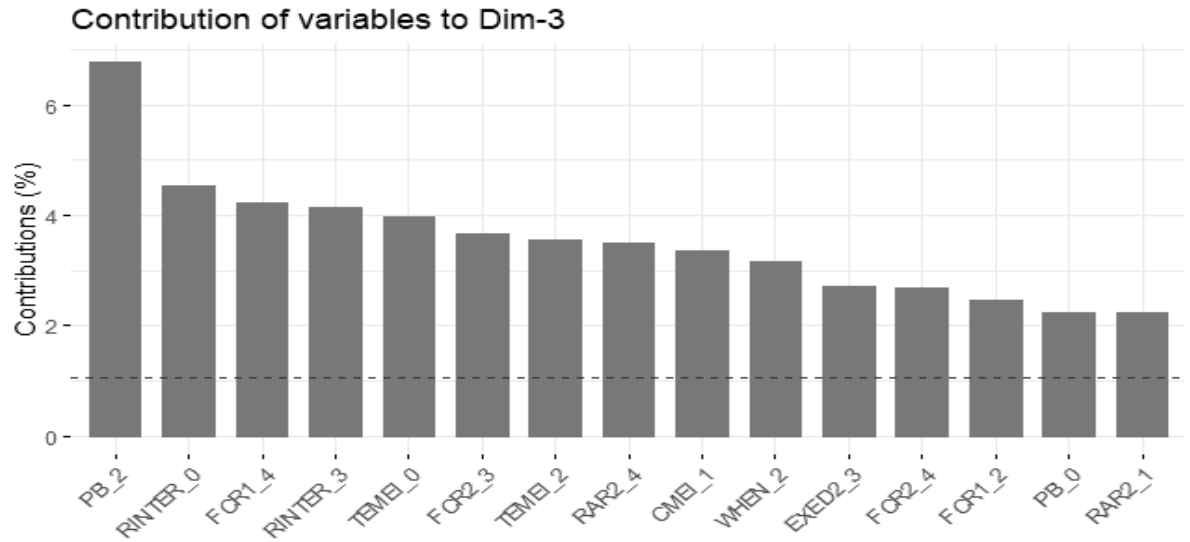

Figure 5. Contribution of variables to Cluster 3

Group 4 consists of professionals who (i) work in the big 4 Certified Public Accountants Offices (TB_0) and in national Certified Public Accountants Offices (TB_4), (ii) the ethical dilemma they encountered are mainly concerned with: (a) the 
undue reliance on the prior year return (EXED1_1), (b) the exploitation of IPRA audit process (EXED2_2), (c) not determining the accuracy of client representations (EXED3_4), (iii) they were engaged to these problems managers (RINTER_3) together with the CFO of the customer(CMEI_1), (iv) the major factor contributing to the resolution of the ethical dilemma was: (a) their experience (FCR1_1 \& FCR1_4) and (b) the communication with a superior (FCR5_4), (v) the ethical dilemmas handled within firm and client not involved (RAR2_4), (iv) their level of morality has changed (RPG2_1).

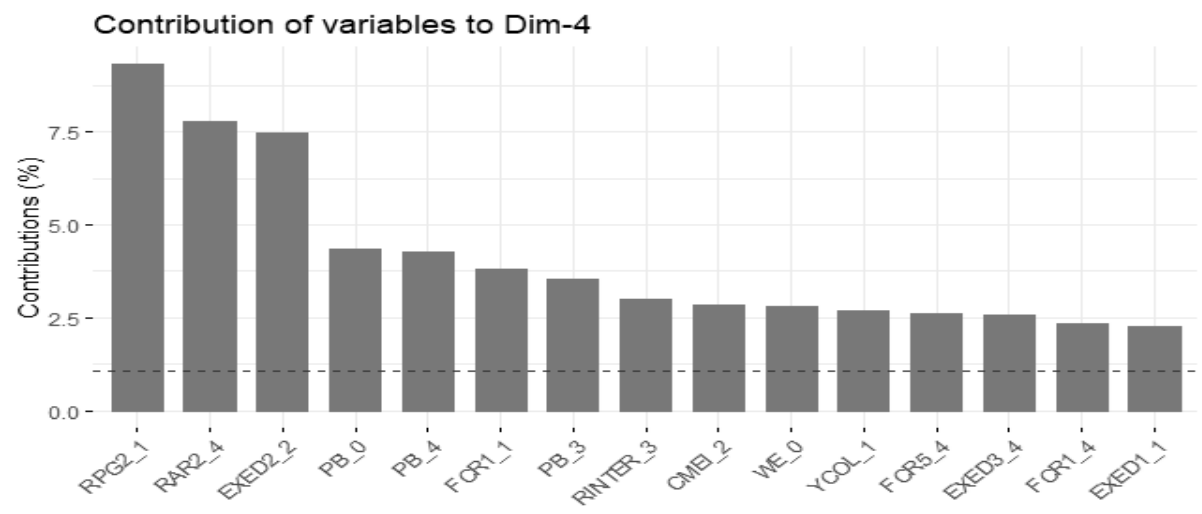

Figure 6. Contribution of variables to Cluster 4

Group 5 consists of professionals who (i) who have working experience more than 15 years (WE_3 \& WE_4) (a) the undue reliance on the prior year return (EXED1_4), (b) the exploitation of IPRA audit process (EXED2_3), (c) not determining the accuracy of client representations (EXED3_4), (ii) the major factor contributing to the resolution of the ethical dilemma was: (a) their experience (FCR1_3) and (b) the communication with a superior (FCR5_2), (iii) the ethical dilemmas handled within firm and client not involved (RAR2_4), (iv) their level of morality has changed (RPG2_1).

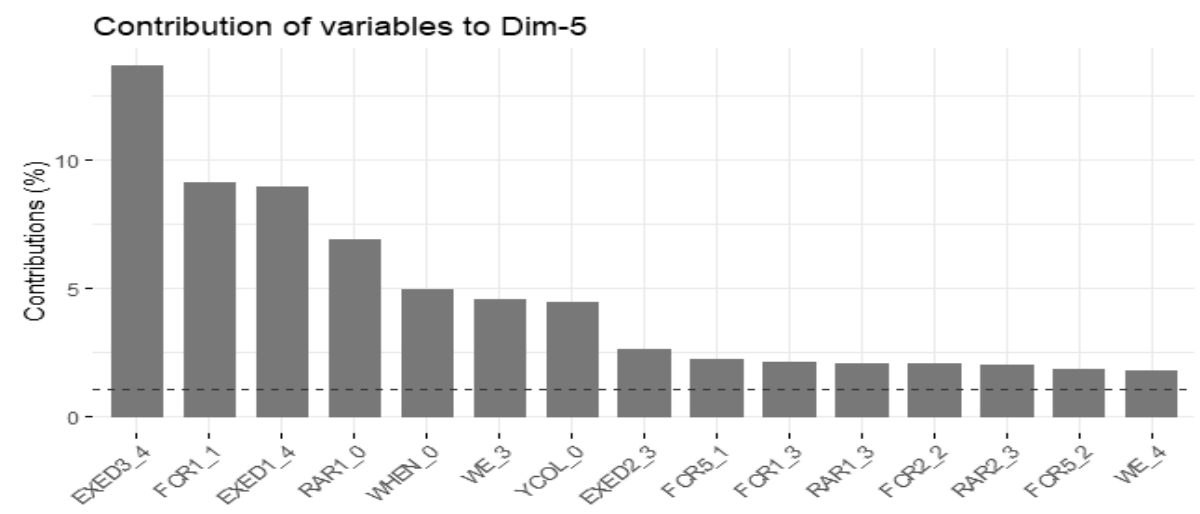

Figure 7. Contribution of variables to Cluster 5 


\section{Conclusions}

The main purpose of this research was to study the level of ethics of certified public accountants and accountants - tax consultants in the period of economic crisis in Greece. These tax professionals were selected as they submit the amount of due taxes at Greek IPRA. We used an interpretative approach with an experimental questionnaire to investigate a particularly complex and controversial issue in the tax field, such as ethics and tax professionals' role on collectability of public revenues.

Our work comes as a contribution to the ongoing dialogue on tax and accountant ethics because it tries to analyze their ethical thinking about the difficult role they have undertaken. The ethical attitude adopted by the tax professional is a complex balance between personal characteristics, the extent to which their personal perspective interprets the law and whether are subject to a code of corporate, personal or professional ethics. Thus, despite the fact that codes of ethics show a strong trend towards ethics, many factors that interact with each other must be taken into account.

Our preliminary results show that tax professionals have an ethical orientation to existing state legislation. However, the ethics of tax professionals are affected by their efforts to maintain their relationships with clients at an excellent level. Furthermore, from the received results, we conclude that tax professionals are aware of the rules of the code of professional ethics and using their judgment they decide what action they will take to avoid unpleasant results. The results of the survey provide us with evidence that, as a whole, tax professionals see their business ethical environments as very powerful. In addition, the results of this survey show that fewer than half of the participants had encountered the dilemma of undue reliance from client regarding profits in the past year. Also, we observe that a majority of selfidentified ethical dilemmas primarily concern client problems such as client pressure, client retention, and late delivery of information and poor client communication. The above were mentioned as the main causes of the creation of ethical dilemmas. Moreover, based on the results of the survey, the most common factors contributing to the resolution of a dilemma are professional experience, client communication and personal ethical values.

Furthermore, the holistic assessment of the interdependence and interaction of all variables has shown that the major ethical dilemmas face by the accountant are mainly concerned with the undue reliance on the prior year return, the exploitation of Greek Independent Public Revenue Authority (IPRA) audit process and the determination of the accuracy of client representations. The major factor contributing to the resolution of the ethical dilemma was their experience and the communication with a superior the ethical dilemmas handled within involved. Last, a considerable percentage of them believe that their level of morality has changed during the period of economic crisis in Greece, thus making them more ethical on tax compliance. 
Finally, this study contributes to business ethics and helps reinforce them, thereby contributing to the increase in the public revenue of the state, which can help Greece to emerge faster from the economic crisis era. Also, as Bobek and Radtke (2007) previous proposed and aligned with this opinion, we recommend as implications of this study the targeting on in-house ethics training and explicitly including rewards and sanctions regarding ethical behavior in performance evaluation systems in tax professionals' firms.

\section{References}

Armstrong, C., Blouin, J. \& Larcker, D. (2012) "The incentives for tax planning", Journal of Accounting and Economics, vol. 53, no. 1-2: 391-411

Backof, A., Bamber, M. \& Carpenter, T. (2016) "Do auditor judgment frameworks help in constraining aggressive reporting? Evidence under more precise and less precise accounting standards", Accounting, Organizations and Society, vol. 51: 1-11

Baird, K. \& Harrison, G. (2017) "The association between organizational culture and the use of management initiatives in the public sector", Financial Accountability \& Management, vol. 33, no. 3: 311-329

Baker, R., Fogarty, T. \& Jones, D. (2014) "Between a rock and a hard place", Qualitative Research in Accounting \& Management, vol. 11, no. 4: 286-316

Battaglini, M., Guiso, L., Lacava, C. \& Patacchini, E. (2019) “Tax professionals: tax-evasion facilitators or information hubs?", NBER Working Paper, No. 25745, Issued in April 2019, NBER Public Economics Program

Bobek, D. \& Radtke, R. (2007) "An experiential investigation of tax professionals' ethical environments", Journal of the American Taxation Association, vol. 29, no. 2: 63-84

Bobek, D., Dalton, D., Daugherty, B., Hageman, A. \& Radtke, R. (2017) “An investigation of ethical environments of CPAs: public accounting versus industry", Behavioral Research in Accounting, vol. 29, no. 1: 43-56

Bobek, D., Dalton, D., Hageman, A. \& Radtke, R. (2018) "An experiential investigation of tax professionals' contentious interactions with Clients", Journal of the American Taxation Association, vol. 41, no. 2: 1-29

Bobek, D., Daugherty, B. \& Radtke, R. (2012) "Resolving audit engagement challenges through communication", Auditing: A Journal of Practice \& Theory, vol. 31, no. 4: 21-45

Bobek, D., Hageman, A. \& Radtke, R. (2015a) "The effects of professional role, decision context, and gender on the ethical decision making of public accounting professionals", Behavioral Research in Accounting, vol. 27, no. 1: 55-78

Bobek, D., Hageman, A. \& Radtke, R. (2015b) “The influence of roles and organizational fit on accounting professionals' perceptions of their firms' ethical environment", Journal of Business Ethics, vol. 126: 125-141 
Bobek, D., Hageman, A.M. \& Radtke, R. (2010) "The ethical environment of tax professionals: partner and non-partner perceptions and experiences", Journal of Business Ethics, vol. 92: 637-654

Cohen, J.R., Dalton, D.W. \& Harp, N.L. (2017) "Neutral and presumptive doubt perspectives of professional skepticism and auditor job outcomes", Accounting, Organizations and Society, vol. 62: 1-20

Cohen, J.R., Dalton, D.W., Holder-Webb, L.L. \& McMillan, J.J. (2018) “An analysis of glass ceiling perceptions in the accounting profession", Journal of Business Ethics, vol. 35: 1-22

Curtis, M., Vinson, J., Conover, T., Lucianetti, L. \& Battista, V. (2017) "National culture and ethical judgment: a social contract approach to the contrast of ethical decision making by accounting professionals and students from the U.S. and Italy", Journal of International Accounting Research, vol. 16, no. 2: $103-120$

Dalton, D., Davis, A.B. \& Viator, R. (2015) "The joint effect of unfavorable supervisory feedback environments and external mentoring on job attitudes and job outcomes in the public accounting profession", Behavioral Research in Accounting, vol. 27, no. 2: 53-76

Darmayasa, N. \& Aneswari, Y.R. (2015) "The Ethical Practice of Tax Consultant Based on Local Culture", Procedia - Social and Behavioral Sciences, vol. 211, no. 11: 142-148

DeZoort, F.T. \& Harrison, P.D. (2018) "Understanding auditors' sense of responsibility for detecting fraud within organizations", Journal of Business Ethics, vol. 149: 859-874

DeZoort, F.T., Harrison, P. \& Edward, S. (2012) “Tax professionals' responsibility for fraud detection: the effects of engagement type and audit status", Accounting Horizons, vol. 26, no. 2: 289-306

Doyle, E., Frecknall-Hughes, J. \& Summers, B. (2014) "Ethics in tax practice: a study of the effect of practitioner firm size", Journal of Business Ethics, vol. 122 , no. 4: 623-641

Drogalas, G., Pazarskis, M., Anagnostopoulou, E. \& Papachristou, A. (2017) "The effect of internal audit effectiveness, auditor responsibility and training in fraud detection", Journal of Accounting and Management Information Systems, vol. 16, no. 4: 434-455

Drogalas, G., Anagnostopoulou, E., Pazarskis, M. \& Petkopoulos, D. (2018) “Tax ethics and tax evasion. Evidence from Greece", Theoretical Economics Letters, vol. 8, no. 5: 1018-1027

Espinosa-Pike, M. \& Barrainkua, I. (2019) "Professional accountants in Spain: a comparative study of ethical and professional values", Spanish Journal of Finance and Accounting, vol. 48: 1-31

Gracia, L. \& Oats, L. (2012) "Boundary work and tax regulation: A Bourdieusian view", Accounting, Organizations and Society, vol. 37, no. 5: 304-321

Greenacre, M. (2007) "Correspondence Analysis in Practice", Second Edition. London: Chapman \& Hall/CRC 
Hageman, A. \& Fisher, D. (2016) "The influence of client attributes and organizational climate on tax professionals", Research on Professional Responsibility and Ethics in Accounting, vol. 20: 31-66

Ishaque, M. (2019) "Managing conflict of interests in professional accounting firms: a research synthesis", Journal of Business Ethics, vol. 159: 1-19

Kadous, K. \& Magro, A.M. (2001) "The effects of exposure to practice risk on tax professionals' judgements and recommendations", Contemporary Accounting Research, vol. 18, no. 3: 451-475

Karagiorgos, A., Drogalas, G., Lazos, G. \& Fotiadou, V. (2019) "Tax policy, tax disharmony, and tax competition: The Situation of Greek economy", Journal of Governance and Regulation, vol. 8, no. 2: 8-16

Karagiorgos, A., Lazos, G. \& Leontiadis, N. (2020) "Taxation efficiency and accounting assisted transparency, insight into a European framework", Journal of Accounting and Taxation, vol. 12, no. 1: 28-38

Kassambara, A \& Mundt, F. (2017) "factoextra: extract and visualize the results of multivariate data analyses", $\mathrm{R}$ package version 1.0.5

Lazos, G. (2016) "The complexity of tax legislation: an aggravating factor for the Greek tax system", 2nd International Conference of Development and Economy, June 9-12, Thessaloniki, Conference proceedings, pp. 202-208

Le, S., Josse, J. \& Husson, F. (2008) "FactoMineR: An R package for multivariate analysis", Journal of Statistical Software, vol. 25, no. 1: 1-18

Long, J. \& Basoglu, A. (2016) "The impact of task interruption on tax accountants' professional judgment", Accounting, Organizations and Society, vol. 55: 96-113

McLeod M.S., Payne G.T. \& Evert R.E. (2016) "Organizational ethics research: a systematic review of methods and analytical techniques", Journal of Business Ethics, vol. 134: 429-443

Mulligan, E. \& Oats, L. (2016) "Tax professionals at work in Silicon Valley", Accounting, Organizations and Society, vol. 52: 63-76

O'Donnell, E., Koch, B. \& Boone, J. (2005) "The influence of domain knowledge and task complexity on tax professionals' compliance recommendations", Accounting, Organizations and Society, vol. 30: 145-165

Pazarskis, M., Drogalas, G. \& Baltzi, K. (2017) "Detecting false financial statements: Evidence from Greece in the period of economic crisis", Investment Management and Financial Innovations, vol. 14, no. 3: 102-112

Pazarskis, M., Lazos, G. \& Drogalas, G. (2019) "Assessing the impact of taxation on mergers in the EU: The case of Greek listed firms", Actual Problems of Economics, vol. 218, no. 8: 113-121

Peres-Neto, P.R., Jackson, A.D. \& Somers, M.K. (2005) "How many principal components? Stopping rules for determining the number of non-trivial axes revisited", Computational Statistics \& Data Analysis, vol. 49, no. 4: 974-997

Saad, N. (2014) "Tax knowledge, tax complexity and tax compliance: taxpayers' view", Procedia - Social and Behavioral Sciences, vol. 109: 1069-1075

Shafer, W. \& Simmons, R. (2008) "Social responsibility, Machiavellianism and tax avoidance: A study of Hong Kong tax professionals", Accounting, Auditing \& Accountability Journal, vol. 21, no. 5: 695-720 